期動脈相で，A群が有意に低下した結果に反映されたものと考えら れた。

244 造影剂使用量最適化を考慮したデュアルヘッドインジェクター の開発一第 2 報

札幌医科大学附属病院 ·放射線部 平野透，小倉圭史，鈴木純平 (株)根本杏林堂 傳法昌幸, 座間味朝之

【目的】第60回総会において我々は最適なタイミングでの生食後押し を可能にしたインジェクターの開発についての概念及びプロトタイ プを用いた臨床応用を報告した. 今回この機能を実機に搭載するこ とが可能となったので, 短時間撮影における生食後しのタイミング 及び造影剤の低減の可能性を検討したので報告する.

【方法】CT装置は東芝社製Aquilion-multi (4DAS), 造影剂自動注入器 は根本杏林堂製DUAL SHOT TypeDを用いた。根本製血中濃度測定 ファントムを用いスキャン時間を16列等の多列化を想定した短時間 撮影(10秒以下)に扔ける最適な生食フラッシュのタイミング及び臨 床における造影剤低減の可能性について検討した。

【結果】血中濃度測定ファントムを用いて多列化を想定した短時間撮 影での検討では撮影開始前に生食フラッシュを行うことにより，撮 影時間内に十分な生食後押しの効果が得ることができた。また撮影 開始前に生食後押しすることによって更なる造影剤量の低減が可能 となった. 本インジェクターは従来のインジェクターでは不可能で あった造影剤を停止させて生食を注入する夕イミングを任意に決定 でき，多列化に伴うマルチスライスCTに対して最も有用なインジェ クターと考える.

245 Dual Injection法と $150 \mathrm{ml}$ 造影剤単独(single法)による腹部CT 造影能の比較

金沢医科大学病院·中央放射線部 山村 博, 大平美和，山田正則

魚谷儀一, 香坂 誠，飛田 明

【目的】近年MDCTの普及は撮影法を変化させ，それと共に造影法最 適化の必要性が出てきた。一方, 造影剂量もいくつかの製剤で $150 \mathrm{ml}$ までの投与が認められるようになり，体重の多い患者でも肝 や桠といった実質臟器に十分な造影効果が得られるようになってき た。しかしながら造影剤による急性腎不全のリスクファクターを有 する症例においては，造影剤の投与量に留意すべきであると思われ る. そこで体重の多い患者 (55kg以上)においてDual Injection法(造影 剤 $100 \mathrm{ml}+$ 生食 $50 \mathrm{ml}$ ) と $150 \mathrm{ml}$ 造影剤単独( (single法)についての腹部CT 造影能を比較検討した。

【使用機器】SOMATOM Sensation16(SIEMENS社製) DUAL SHOT (根 本杏林堂社製), 造影剂( ヨード含有量 $300 \mathrm{mgI}, 350 \mathrm{mgI}, 370 \mathrm{mgI}$ ) 【方法】対象患者は体重 $55 \mathrm{~kg}$ 以上で, 年齢は80歳未満. 注入速度は造

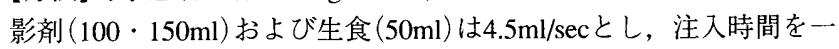
定とした。撮影方法は造影剂注入開始後 $30,70,180 \mathrm{sec}$ と 3 phase撮 影した。各時相において肝実質・大動脈・門脈に関心領域 (ROI)を 設定しCT值を測定, 有意差検定を行った。 また, 肝腫瘤性病変の造 影能について視覚的評価を行った。

【結果・考察】統計学的には体重75kgまでは有意差は見られず, 肝腫 瘤性病変の造影能についてもDual Injection法は150ml造影剂単独 (single法)と遜色ない画像が得られ，身体的経済的負担の軽減につな がると思われる.

246 MDCTを用いた小児心血管造影CTの検討一第 2 報 イン ジェクター同期機構の有用性について一

大阪府立母子保健総合医療センター・放射線科阿部修司，水野直人 沖口忠司，三原一博

【目的】当センターのSDCTによる小児の心血管造影CT検査における 注入条件については, 第53回総会に扔いて報告し, その結果から,
ヨード含有量 $150 \mathrm{mgl} / \mathrm{ml}$ の造影棛を体重 $1 \mathrm{~kg}$ あたり $4 \mathrm{cc} の$ 注入量を用 いて行ってきた。装置がSDCTから16DAS MDCTに更新されたこと により，撮影時間が大幅に短縮され，造影剤量の低減も期待され た。しかし，対象とする先天性心疾患の患者は，心血管の血行動態 の個人差が大きく，必要とされる造影剤量も個人差が大きいと考え られた。 今回, 装置の更新に伴い, CT装置と同期機構を有するイン ジェクター装置が導入されたので，小児の心血管造影CT検査に対す る有用性を，造影剂使用量および得られた画像から検討を行ったの で報告する。

【方法】インジェクターの同期機構は，インジェクターの造影剤注入 開始スイッチに連動して，CT装置のRealPrepスキャンが開始され る.そして，本スキャンが開始されると，CT装置からの本スキャン 開始信号を受けて，あらかじめ設定した時間後に造影郕の注入を停 止する。また，生理食塩水の後押し注入が設定されていると，注入 が行われる.インジェクター同期機構を用いた場合の造影剤注入量 と，設定されていた造影剤量から，その割合を求めた。血管系の 造影の良否を, 左右心房心室が一様に造影されているかを, CT值を 測定して検討を行った。

【結果·考察】インジェクター同期機構を用いることで, 注入量を減 少させることが可能であった．また，生理食塩水の後押しで，流入 経路となる部位のCT值が高值となる割合が減少した．これらのこと から，小児心血管造影CTにおけるインジェクター同期機構は有用で あると考えられた。

\section{7 消化管撮影における直接変換型FPDの透視画像の検討} 慶應義塾大学病院・放射線技術室 望月干種, 增田裕二, 島田泰冨 直井貴宣，松田美智恵，西平源幸，都築史郎

【目的】現在パルス透視は, 血管撮影等に広く使用されている. 当院 では，直接型FPDにCアームを自由に動かすことのできる装置で撮 影を行っている。透視においては連続透視, パルス透視を瞬時に切 り替えることが可能である。 そこで, それぞれの透視の物理評価, 視認評価, 消化管撮影における透視像を臨床評価し検討した。

【方法】物理評価としてガラス線量形を用いアクリル17cm, $10 \mathrm{~cm} に て ~$ 一分間の表面線量, 透過線量を測定し, またS/N比を求めた。視認 評価は，バーガーファントムまた自作回転ファントムを用いて，限 界解像度及び識別能を評価した，臨床評価は，消化管撮影における それぞれの透視像を評価した。

【結果】連続透視, パルス透視とも表面線量に有意差はなくほほ同程 度である.S/N比は，パルス透視が若干良い。また，視認評価にお いてもパルス透視のほうが優れていた，臨床評価においては，目的 により2つの透視機能を組み合わせて使用することにより有効性が 確認できた。

【考察】現在, FPDは各メーカーともいかに低線量で透視画像を良く するか検討されている．被写体や装置をあまり動かすことのない血 管造影などはFPDパルス透視は有効である，しかし，消化管撮影は 瞬時に被写体やFPDを動かすことにより病変を発見しなければなら ない. その点若干残像の多いパルス透視より連続透視のほうが有効 である.しかし, 圧迫撮影や後壁二重造影など被検者の微妙な動き に対してはパルス透視は有効である. 今後は, いかに低線量, 低 レートパルス透視において被曝線量を少なくしS/N比を上げて良質 な透視像を得ることが課題であろう.

248 直接変換型FPD搭載透視装置における被ばく低減の一考 聖マリアンナ医科大学病院・画像診断センター 古川博明, 北川由香 馬野清次，吉田和良，長野高広

【目的】当院のFPD搭載透視装置は透視条件設定が数種ある. FPD装 置と従来1.I.-F/S装置の消化管検査における被ばく線量を比較し, FPD装置における被ばく線量低減への可能性について検討する. 